\title{
Mechanisms of Antibacterial Action of Bacitracin
}

\author{
BY J. L. SMITH* AND E. D. WEINBERG \\ Department of Bacteriology, Indiana University, Bloomington, Indiana, U.S.A.
}

(Received 3 October 1961)

\begin{abstract}
SUMMARY
At minimal bacteriostatic concentrations, bacitracin had four distinct actions on Staphylococcus aureus: $(a)$ prevention of growth; $(b)$ induction of lysis; (c) suppression of induced enzyme synthesis; $(d)$ stimulation of the reduction of 2,3,5-triphenyltetrazolium chloride. In contrast, penicillin and cycloserine had activities $(a)$ and $(b)$ but neither $(c)$ nor $(d)$, and chloramphenicol had activities $(a)$ and $(c)$ but neither $(b)$ nor $(d)$. With bacitracin, properties $(a)$ and $(b)$ but neither $(c)$ nor $(d)$ were enhanced by $\mathrm{Zn}^{2+}$; other metal ions were inactive. Sequential inactivation of bacitracin by autoclaving revealed that the bacteriostatic property was quite labile whereas the other three activities were more heat resistant. Thus, although several distinct mechanisms have been demonstrated whereby bacitracin can injure bacterial cells, the present data do not indicate which of these, if any, is associated with the primary biochemical lesion that results in suppression of growth.
\end{abstract}

\section{INTRODUCTION}

The literature on the biochemical mechanisms of drug action indicates that, of the antibiotics in clinical use, bacitracin is unique: at minimal bacteriostatic concentrations it apparently possesses a dual mode of action. On the one hand. in common with penicillin and cycloserine, bacitracin suppresses the synthesis of bacterial cell walls. For example, the drug causes Staphylococcus aureus to lyse (Crawford \& Abraham, 1957), to form protoplasts (Abraham, 1957), to accumulate uridine nucleotides (Abraham \& Newton, 1958; Park, 1958, 1960), and to be unable to incorporate radioactive amino acids into cell wall mucopeptides (Park, 1958; Mandelstam \& Rogers, 1959). On the other hand, in common with chloramphenicol, bacitracin prevents $S$. aureus from synthesizing such proteins as $\beta$-galactosidase (Creaser, 1955; Gale \& Folkes, 1955) and $\alpha$-haemolysin Hinton \& Orr, 1960). However, bacitracin does not prevent $S$. aureus from incorporating radioactive lysine into cell protein (Park, 1960) nor does the drug inhibit the biosynthesis of $M$ protein by streptococci (Dr T. D. Brock, personal communication).

The thermal and storage stability of bacitracin is enhanced by the presence of an equimolar concentration of $\mathrm{Zn}^{2+}$ (Gross, 1954) and the antibacterial action of the drug is potentiated by an excess concentration of $\mathrm{Zn}^{2+}$ (Weinberg, 1959). Unfortunately, in published studies on the biochemical mechanisms of action of the drug, the role of $\mathrm{Zn}^{2+}$ has not been considered and the divergent results obtained in the studies on suppression of protein synthesis might have been caused in part by the lack of control of the metallic environment. The experiments reported in the present

* Present address : Department of Microbiology, University of Chicago, Chicago 37, Illinois, U.S.A. 
paper were designed to: (a) confirm the existence of the dual mechanism of action; (b) determine whether either of the two mechanisms is primarily responsible for the antibiotic action of the drug; (c) learn whether $\mathrm{Zn}^{2+}$ is required for either mechanism.

\section{METHODS}

Organism, culture medium, and antibiotics. A coagulase positive strain of Staphylococcus aureus, designated S-14 in our Departmental stock culture collection, was used. The components of the culture medium are listed in Table 1. The first nine ingredients were dissolved in de-ionized water, the mixture adjusted to $\mathrm{pH} \mathbf{7 \cdot 4}$ with $\mathrm{NaOH}$, and the medium was sterilized by autoclaving at $121^{\circ}$ for $15 \mathrm{~min}$. Solutions of glucose and vitamin mixture were autoclaved separately and added aseptically to the medium before inoculation. Solidified medium, when desired, was obtained by the inclusion of $2 \%(w / v)$ agar (Difco, Noble) in the liquid medium; the agar medium was autoclaved and then poured into Petri plates. The antibiotics used were bacitracin and potassium penicillin $\mathrm{G}$ (California Corporation for Biochemical Research), D-cycloserine (Commercial Solvents Corporation), and chloramphenicol (Parke, Davis and Company); these were dissolved in de-ionized water and sterilized by passage through ultra-fine sintered glass filters. Fresh solutions were prepared for each experiment.

Table 1. Composition of the basal medium

\begin{tabular}{|c|c|c|}
\hline \multirow[b]{2}{*}{ Compound } & \multicolumn{2}{|c|}{ Concentration } \\
\hline & $\mu \mathrm{g} . / \mathrm{ml}$ & $M \times 10^{-6}$ \\
\hline Casamino acids* & 10,000 & - \\
\hline Uracil & $1 \cdot 12$ & 10 \\
\hline $\mathrm{K}_{2} \mathrm{HPO}_{4}$ & 3,140 & 18,100 \\
\hline $\mathrm{KH}_{2} \mathrm{PO}_{4}$ & 950 & 6,900 \\
\hline $\mathrm{MgSO}_{4} \cdot 7 \mathrm{H}_{2} \mathrm{O}$ & 616 & 2,500 \\
\hline $\mathrm{CaCl}_{2}$ & 278 & 2,500 \\
\hline $\mathrm{FeSO}_{4} \cdot 7 \mathrm{H}_{2} \mathrm{O}$ & 28 & 100 \\
\hline $\mathrm{MnSO}_{4} \cdot \mathrm{H}_{2} \mathrm{O}$ & $3 \cdot 4$ & 20 \\
\hline Citric acid. $\mathrm{H}_{2} \mathrm{O}$ & 2,100 & 10,000 \\
\hline D-Glucose† & 1,800 & 10,000 \\
\hline Nicotinic acid & $1 \cdot 23$ & 10 \\
\hline Thiamine.HCl & 0.337 & $1 \cdot 0$ \\
\hline Biotin & 0.001 & 0.004 \\
\hline
\end{tabular}

* Bacto (Difco certified) Casamino acids.

$\dagger$ Lactose $\left(3600 \mu \mathrm{g} . / \mathrm{ml}\right.$.; $\left.10,000 \times 10^{-6} \mathrm{M}\right)$ was substituted for glucose to obtain cocci for the mannitol induction tests because glucose-grown cocci contained mannitol dehydrogenase.

Determination of bacteriostatic and bacteriolytic activities of the antibiotics. The bacteriostatic activities of the antibiotics were determined by inoculating a series of liquid cultures containing different quantities of the respective antibiotics and incubated at $37^{\circ}$ on a rotary shaker. Erlenmeyer flasks $(125 \mathrm{ml}$.) containing $25 \mathrm{ml}$. of medium inoculated with about $5 \times 10^{5}$ viable cocci/ml. culture medium were used. At intervals of time, $1 \mathrm{ml}$. of culture fluid was removed from each flask and diluted to $5 \mathrm{ml}$. with de-ionized water for measurement of optical density (o.D.) in a Bausch \& Lomb Model Spectronic 20 Spectrophotometer at a wavelength of $625 \mathrm{~m} \mu$. 
The ability of the antibiotics to suppress cell wall synthesis was determined by exposing growing organisms to the drugs and measuring the extent of lysis. Cultures grown on solid medium and in liquid medium were used. The tests on solid medium were made on agar surfaces that had been inoculated by spreading about $5 \times 10^{6}$ viable cocci and incubated for $4 \mathrm{hr}$. at $37^{\circ}$. At that time, a thin film of visible growth had developed. Filter-paper disks containing $100 \mu \mathrm{g}$. antibiotic were placed on the agar surfaces and the plates incubated overnight at $37^{\circ}$. The diameters of the zones in which visible growth disappeared were measured and the areas of lysis calculated from these data.

The lytic tests on cocci grown in liquid medium were made by incubating shaken cultures for $7 \mathrm{hr}$; at that time the cocci were harvested by centrifugation and suspended in $10 \mathrm{ml}$. (in $50 \mathrm{ml}$. Erlenmeyer flasks) of fresh medium lacking Casamino acids. The suspension of cocci was adjusted so that a 1/5 dilution gave an o.D. of 0.25 at wavelength $625 \mathrm{~m} \mu$. Different quantities of the respective antibiotics were added to the flasks which were then incubated at $37^{\circ}$ on a rotary shaker for $16 \mathrm{hr}$. The extent of lysis at that time was determined by obtaining the o.D. of a 1/5 dilution of each culture.

Determination of the ability of the antibiotics to suppress induced enzyme synthesis. The ability of the antibiotics to suppress protein synthesis was determined by exposing the cocci to an inducing substrate in the presence of antibiotic and observing the extent of inhibition of induced enzyme formation. Portions (100 ml.) of liquid medium contained in Erlenmeyer flasks (500 ml.) were inoculated with the test organism (so that the culture medium contained about $5 \times 10^{7}$ viable cocci $/ \mathrm{ml}$.) and incubated at $37^{\circ}$ on a rotary shaker for $16 \mathrm{hr}$. The cocci were harvested by centrifugation, washed once in $0.025 \mathrm{M}$-phosphate buffer $(\mathrm{pH} \mathrm{7.5)}$ ) and then inoculated into $25 \mathrm{ml}$. portions of the modified liquid medium contained in $125 \mathrm{ml}$. Erlenmeyer flasks. Sufficient cocci were used to obtain a concentration of 5 to $10 \times 10^{9}$ viable cocci/ml. culture medium. The modification of the medium consisted in the omission of glucose and the decrease of the Casamino acids concentration from 10,000 to $1000 \mu \mathrm{g}$. $/ \mathrm{ml}$. In earlier tests, the latter quantity of Casamino acids had been shown to contain enough nitrogenous material for enzyme synthesis, and plate counts indicated that under these conditions the number of viable cocci was not altered during the $5 \mathrm{hr}$. period of induction. Different quantities of the respective antibiotics were included in the experimental flasks. In the tests for suppression of the synthesis of $\beta$-galactosidase, $10 \mathrm{~mm}(1800 \mu \mathrm{g} . / \mathrm{ml}$.) glucose was included in the control non-induced cultures and $10 \mathrm{~mm}(3600 \mu \mathrm{g} . / \mathrm{ml}$. $)$ lactose was included in the flasks in which synthesis of induced enzyme was desired. In tests for the suppression of the synthesis of mannitol dehydrogenase, $10 \mathrm{mM}(3600 \mu \mathrm{g} . / \mathrm{ml}$.) lactose was included in the control (non-induced) flasks and $10 \mathrm{~mm}(1820 \mu \mathrm{g} . / \mathrm{ml}$.) mannitol in flasks in which induction was desired. The flasks were incubated at $37^{\circ}$ on a rotary shaker for $5 \mathrm{hr}$. to allow induction to occur. The cocci were then harvested by centrifugation and washed once in $0.025 \mathrm{~m}$-phosphate buffer $(\mathrm{pH} \mathrm{7.5})$ in the $\beta$-galactosidase tests and at $\mathrm{pH} 7 \cdot 0$ in the mannitol dehydrogenase tests.

The activity of $\beta$-galactosidase was determined spectrophotometrically at a wavelength of $425 \mathrm{~m} \mu$ (Lederberg, 1950). The protein content of the cocci used in the assay was $10 \mathrm{mg}$./sample as determined by the method of Robinson \& Hogden (1940). The assay of mannitol dehydrogenase was indirect inasmuch as the forma- 
tion of organic acids rather than dehydrogenation was measured. Into each $125 \mathrm{ml}$. Erlenmeyer flask was placed $1.0 \mathrm{ml}$. coccal suspension (about $10 \mathrm{mg}$. protein) obtained from various experimental flasks and $10 \mathrm{mg}$. of mannitol. The total volume was adjusted to $10 \mathrm{ml}$. with de-ionized water and the flasks incubated at $37^{\circ}$ on a rotary shaker for $1 \mathrm{hr}$, at which time the experiment was stopped by the addition of $2.5 \mathrm{ml}$. of $95 \%(\mathrm{v} / \mathrm{v})$ ethanol in water. The quantity of acids that formed was determined by titration with $0.005 \mathrm{~N}-\mathrm{NaOH}$.

Determination of the effects of antibiotics on the reduction of 2,3,5-triphenyltetrazolium chloride $(T T C)$. Portions $(100 \mathrm{ml}$.) of the liquid medium contained in Erlenmeyer flasks (500 ml.) were inoculated with the organisms and incubated at $37^{\circ}$ on a rotary shaker for $16 \mathrm{hr}$. The cocci were harvested by centrifugation and washed once in $0.025 \mathrm{M}$-phosphate buffer $(\mathrm{pH} \mathrm{7 \cdot 0)}$. The following ingredients were placed into $25 \times 200 \mathrm{~mm}$. test tubes contained in an ice bath: $1.0 \mathrm{ml}$. of $0.025 \mathrm{M}$ phosphate buffer ( $\mathrm{pH} \mathrm{7.0)} ; 100 \mu \mathrm{g}$. TTC; $100 \mu \mathrm{g}$. of glucose, sodium formate or glycerol, or $10 \mathrm{mg}$. of $95 \%(\mathrm{v} / \mathrm{v})$ ethanol in water; different quantities of antibiotics; enough cocci to give $2 \mathrm{mg}$. protein. The concentrations of antibiotics tested were per ml. 0-50 $\mu \mathrm{g}$. bacitracin or chloramphenicol, 0-10 $\mu \mathrm{g}$. potassium penicillin $\mathrm{G}$, $0-100 \mu \mathrm{g}$. of cycloserine. The total volume was adjusted to $5 \mathrm{ml}$. with de-ionized water. Control tubes that lacked substrate or antibiotic, or both, were included in each experiment. The tubes were incubated statically for $30 \mathrm{~min}$. in a water bath at $37^{\circ}$; they were then returned to the ice bath and $5 \mathrm{ml}$. acetone added to dissolve the reduced TTC. The cocci were removed by centrifugation and the o.D. of the reduced TTC was determined at wavelength $525 \mathrm{~m} \mu$.

\section{RESULTS}

The ability of bacitracin, chloramphenicol, penicillin, and cycloserine to inhibit growth of Staphylococcus aureus is shown in Table 2. The presence of added $\mathrm{Zn}^{2+}$ at $1 \times 10^{-5} \mathrm{M}$ increased the bacteriostatic activity of bacitracin twofold and at $1 \times 10^{-4} \mathrm{M}$ 10-fold. The presence of added $5 \times 10^{-4} \mathrm{M}$-disodium ethylenediaminetetra-acetic acid (EDTA) decreased the growth inhibitory action of bacitracin by a factor of ten. Neither the bacteriostatic activity of the three other antibiotics nor the rate of growth of cocci cultured in the absence of the antibiotics was affected by $\mathrm{Zn}^{2+}$ or by EDTA.

The ability of bacitracin, penicillin and cycloserine to induce lysis of Staphylococcus aureus grown on solid medium is indicated in Table 3. Lysis was obtained consistently when the antibiotics were added to $4 \mathrm{hr}$. cultures; but when the addition was delayed beyond $6 \mathrm{hr}$, , no lytic activity was detected. Chloramphenicol was unable to induce lysis of cultures of any age. In Table 3, it may be noted that EDTA suppressed the lytic activity of bacitracin and penicillin and had a lesser depressing effect on cycloserine. The presence of added $\mathrm{Zn}^{2+}$ enhanced considerably the lytic action of bacitracin but did not influence penicillin or cycloserine. The concentration used of EDTA and $\mathrm{Zn}^{2+}$ had no effect on the growth of the test organisms. Despite previous reports that in some experimental systems the antibacterial action of penicillin and cycloserine is affected moderately by $\mathrm{Co}^{2+}$, and $\mathrm{Cu}^{2+}$ and $\mathrm{Fe}^{2+}$, respectively (Weinberg, 1957), in the present study the lytic action of penicillin, cycloserine and bacitracin was not altered by added $\mathrm{Co}^{2+}, \mathrm{Cu}^{2+}, \mathrm{Fe}^{2+}$, or $\mathrm{Mn}^{2+}$. 
Bacitracin, penicillin and cycloserine were each able to induce lysis of Staphylococcus aureus grown in liquid medium (Fig.1) provided that the procedure described in Methods was used; i.e. resuspension in fresh medium lacking Casamino acids. When the cocci were allowed either to remain in the staled culture medium or when they were transferred to fresh medium containing per ml. more than $100 \mu \mathrm{g}$. Casamino acids, lysis by the three antibiotics was suppressed. For example, the

Table 2. Comparison of the growth-inhibitory concentrations of certain antibiotics with the concentrations necessary to inhibit enzyme synthesis in Staphylococcus aureus

\begin{tabular}{|c|c|c|c|c|c|}
\hline & & & & $\begin{array}{r}\text { Concentra } \\
\text { biotic th } \\
50 \% \text { o } \\
\text { synthesis } \\
\text { enz }\end{array}$ & $\begin{array}{l}\text { n of anti- } \\
\text { inhibited } \\
\text { he bio- } \\
\text { inducible } \\
\text { nes }\end{array}$ \\
\hline & $\begin{array}{l}\text { Concen } \\
\text { prevented }\end{array}$ & $\begin{array}{l}\text { on of an } \\
\text { f-maxim }\end{array}$ & $\begin{array}{l}\text { ic that } \\
\text { rowth at }\end{array}$ & & Mannito \\
\hline Compound & $20 \mathrm{hr}$. & $40 \mathrm{hr}$. & $60 \mathrm{hr}$. & sidase & genase \\
\hline & Antibiot & ncentrat & $u \mathrm{~g} . / \mathrm{ml})$. & & \\
\hline tracin & $6 \cdot 0$ & $36 \cdot 5$ & $71 \cdot 0$ & $5 \cdot 2$ & $10 \cdot 8$ \\
\hline $\mathrm{racin}+10^{-4} \mathrm{M}-\mathrm{Zn}^{2+}$ & 0.5 & $3 \cdot 5$ & $7 \cdot 5$ & $\mathbf{2 \cdot 2}$ & $10 \cdot 0$ \\
\hline camphenicol & $2 \cdot 2$ & $4 \cdot 8$ & $7 \cdot 7$ & $8 \cdot 4$ & $12 \cdot 0$ \\
\hline lin $G$; $K$ salt & 0.005 & $0 \cdot 015$ & $0 \cdot 043$ & $>\mathbf{2 \cdot 0}$ & $>2 \cdot 0$ \\
\hline serine & $4 \cdot 5$ & $16 \cdot 5$ & $18 \cdot 2$ & $>90$ & $>90$ \\
\hline
\end{tabular}

Table 3. Effect of EDT $A$ and $Z n^{2+}$ on the ability of certain antibiotics to lyse Staphylococcus aureus grown on solid medium

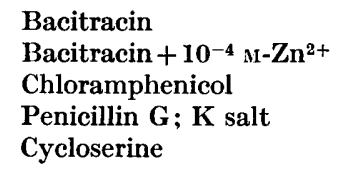

$$
\text { Addition to basal medium }
$$

\begin{tabular}{|c|c|c|c|c|c|c|c|c|c|c|}
\hline \multirow[b]{3}{*}{ Antibiotic } & \multicolumn{10}{|c|}{ Addition to basal medium } \\
\hline & \multicolumn{4}{|c|}{ EDTA (м) } & \multirow{2}{*}{$\begin{array}{c}\text { Nothing } \\
\text { added }\end{array}$} & \multicolumn{5}{|c|}{$\mathrm{Zn}^{2+}(\mathrm{M})$} \\
\hline & $1 \times 10^{-3}$ & $1 \times 10^{-4}$ & $1 \times 10^{-5}$ & $1 \times 10^{-6}$ & & $1 \times 10^{-6}$ & $1 \times 10^{-5}$ & $1 \times 10^{-4}$ & $1 \times 10^{-3}$ & $1 \times 10^{-2}$ \\
\hline Bacitracin & $2 \cdot 6^{*}$ & $2 \cdot 6$ & $3 \cdot 3$ & $\mathbf{3 \cdot 0}$ & $4 \cdot 3$ & $\mathbf{3 \cdot 8}$ & $4 \cdot 1$ & 4.9 & $6 \cdot 6$ & $8 \cdot 7$ \\
\hline Penicillin G; K salt & $13 \cdot 8$ & $17 \cdot 3$ & $16 \cdot 8$ & $17 \cdot 3$ & $20 \cdot 8$ & $20 \cdot 8$ & $20 \cdot 8$ & $20 \cdot 8$ & $20 \cdot 8$ & $20 \cdot 8$ \\
\hline Cycloserine & $6 \cdot 6$ & $7 \cdot 1$ & $7 \cdot 6$ & $7 \cdot 1$ & $7 \cdot 6$ & $7 \cdot 6$ & $7 \cdot 6$ & $7 \cdot 6$ & $7 \cdot 6$ & $7 \cdot 6$ \\
\hline
\end{tabular}

* Area of the zone of lysis in cm..$^{2}$ including the area of the disk which is $1.3 \mathrm{~cm} .{ }^{2}$. The antibiotic impregnated disks were placed on the agar surfaces after visible growth appeared; the extent of lysis was observed $16 \mathrm{hr}$. later.

percentage decreases in turbidity caused by $100 \mu \mathrm{g}$. bacitracin per $\mathrm{ml}$. in the presence of $0,100,250$, or $500 \mu \mathrm{g}$. Casamino acids were $43 \cdot 5,40 \cdot 0,30 \cdot 5$ and $\mathbf{2 6} \cdot \mathbf{0}$, respectively. That this concentration of bacitracin possessed antibacterial action in cultures in which lysis was suppressed was shown by the fact that a $95 \%$ decrease in the viable count occurred in such cultures during the $16 \mathrm{hr}$. of incubation. Later experiments showed that the initial period of growth could be extended to at least $16 \mathrm{hr}$. without interfering with the subsequent lytic process; however, the time of contact between the antibiotics and cocci could not be reduced if maximum lysis was to be obtained. It may be observed in Fig. 1 that $5 \times 10^{-4} \mathrm{M}$ added $\mathrm{Zn}^{2+}$ enhanced strongly the lytic action of bacitracin. The addition of $1 \times 10^{-4} \mathrm{M}$-EDTA in the place of $\mathrm{Zn}^{2+}$ markedly depressed the activity of the drug. 


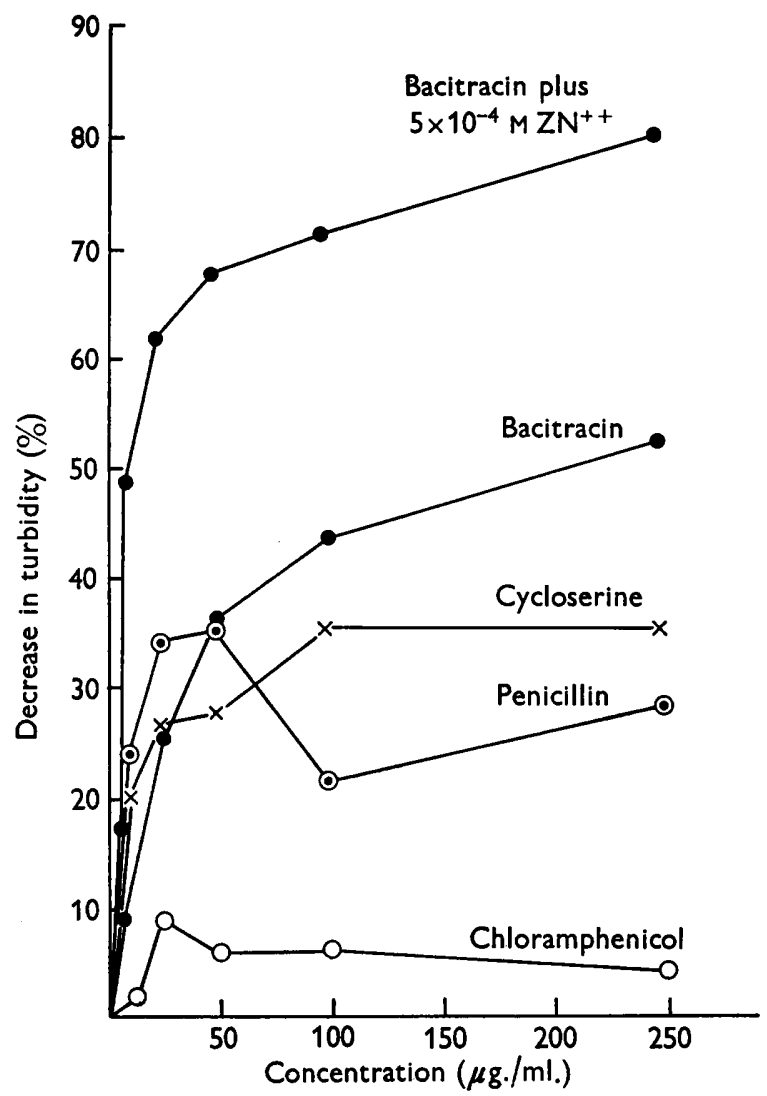

Fig. 1. Ability of antibiotics to lyse Staphylococcus aureus grown in liquid medium. The compounds were added to $7 \mathrm{hr}$. cocci and the extent of lysis observed after a $16 \mathrm{hr}$. period of incubation.
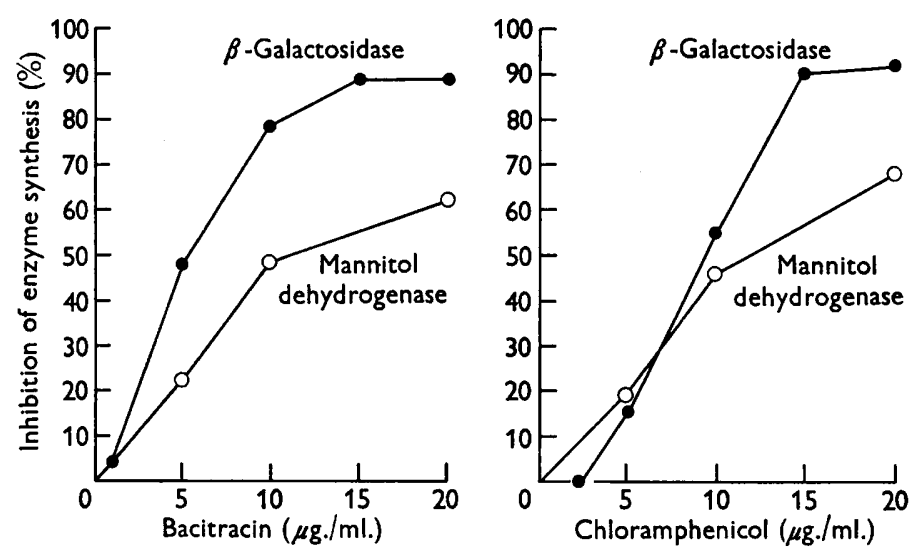

Fig. 2. Effect of bacitracin and chloramphenicol on the ability of Staphylococcus aureus to synthesize inducible enzymes. The antibiotics were added to $16 \mathrm{hr}$. cocci and the activity of the enzymes measured after a $5 \mathrm{hr}$. period of induction. 
For example, the percentage decrease in turbidity caused by $25 \mu \mathrm{g}$. bacitracin $/ \mathrm{ml}$. in the presence of $(a) 1 \times 10^{-4} \mathrm{M}-\mathrm{EDTA},(b)$ neither EDTA nor added $\mathrm{Zn}^{2+}$, or $(c)$ added $5 \times 10^{-4} \mathrm{M}-\mathrm{Zn}^{2+}$ was 5,26 , and 62 , respectively. In the absence of bacitracin, the cocci were neither killed nor lysed by EDTA or $\mathbf{Z n}^{2+}$.

The content of $\beta$-galactosidase in non-multiplying cocci which had been incubated in the presence of lactose or galactose was fifteen or twenty times more, respectively, than that of non-induced cocci. Non-multiplying cocci which had been incubated in the presence of mannitol contained thirty times more mannitol dehydrogenase than did non-induced cocci. The ability of minimal bacteriostatic concentrations of bacitracin and chloramphenicol to suppress induced enzyme synthesis by Staphylococcus aureus is shown in Fig. 2 and in Table 2. Unexpectedly, added $\mathrm{Zn}^{2+}$ had essentially no effect on the activity of bacitracin in this test system (Table 2). It also may be noted in Table 2 that concentrations of penicillin and cycloserine much greater than the minimal bacteriostatic concentrations were unable to suppress enzyme formation.

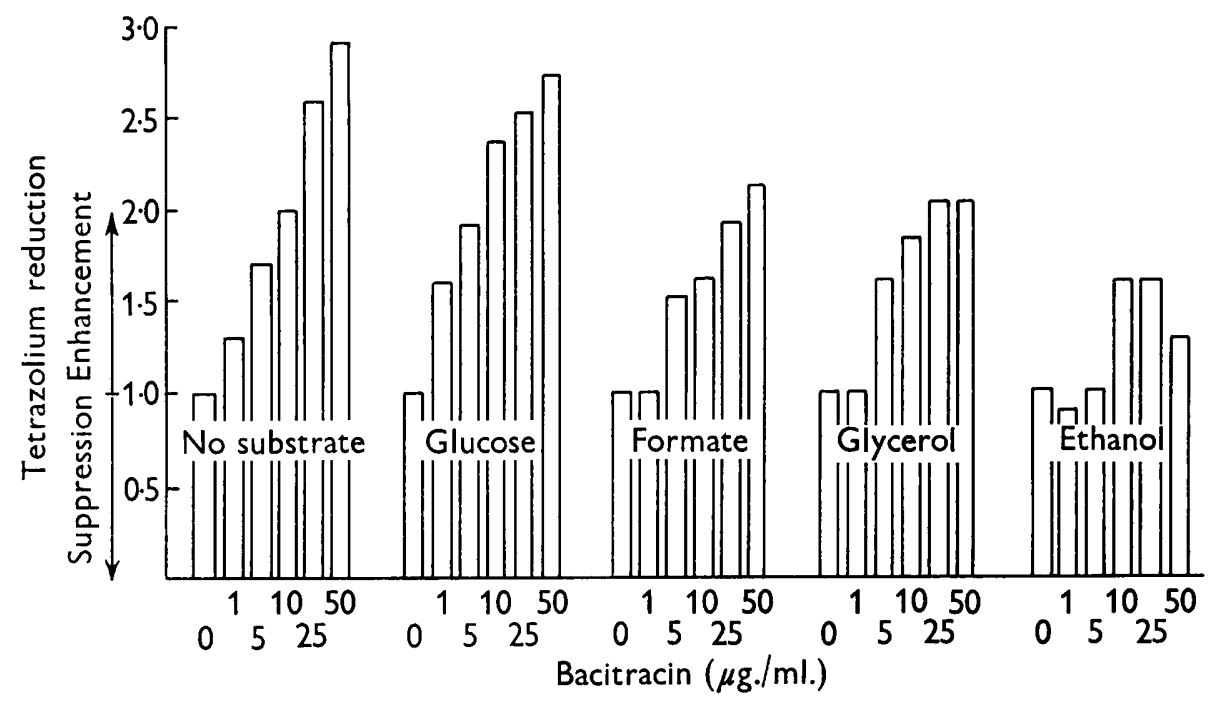

Fig. 3. Effect of bacitracin on the ability of Staphylococcus aureus to reduce 2,3,5triphenyltetrazolium chloride (TTC) in the presence of various substrates. The values on the ordinate scale represent the ratios of the o.D. of the tubes containing bacitracin to those lacking bacitracin. The antibiotic was added to $16 \mathrm{hr}$. cocci and the quantity of reduced TTC measured after a $30 \mathrm{~min}$. period of incubation.

The ability of minimal bacteriostatic concentrations of bacitracin to stimulate the reduction of 2,3,5-triphenyltetrazolium chloride (TTC) by washed whole cocci of Staphylococcus aureus is indicated in Fig. 3. Added $\mathrm{Zn}^{2+}$ was unable to enhance this activity of bacitracin; indeed, the test system was remarkably sensitive to $\mathrm{Zn}^{2+}$ since as little as $1 \times 10^{-5} \mathrm{M}$ completely suppressed the reduction of TTC. Other metallic ions $\left(\mathrm{Cu}^{2+}, \mathrm{Co}^{2+}, \mathrm{Fe}^{2+}, \mathrm{Mn}^{2+}\right)$ had no effect either on the test system or on bacitracin activity. The influence of EDTA on bacitracin activity could not be tested since, as with $\mathrm{Zn}^{2+}$, EDTA alone inhibited reduction of TTC by the cocci. Reduction of TTC was neither stimulated nor inhibited by chloramphenicol, penicillin or cycloserine. 
Sequential inactivation by heat of the four biological properties of bacitracin described above is shown in Fig. 4. Samples of bacitracin at $0 \cdot 1 \%(w / v)$ in deionized water ( $\mathrm{pH} 6 \cdot 3$ ) were autoclaved for 15,30 , and $60 \mathrm{~min}$. at $121^{\circ}$ and then assayed to determine the extent of inactivation of each property. The bacteriostatic activity of bacitracin was eliminated by autoclaving for $15 \mathrm{~min}$; longer periods were necessary to destroy the ability of bacitracin to suppress induced enzyme synthesis, stimulate reduction of TTC, or induce lysis.

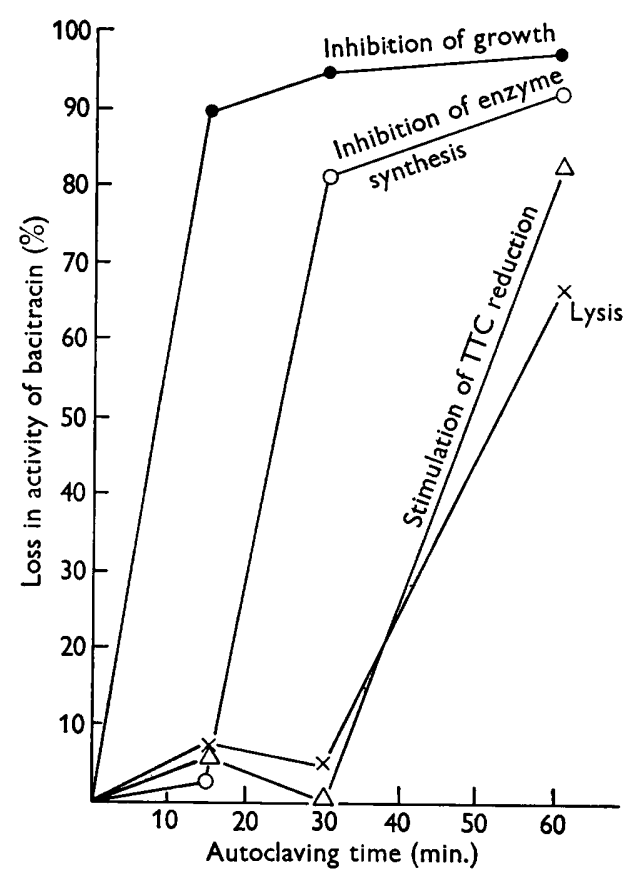

Fig. 4. Effect of autoclaving on the biological properties of bacitracin.

\section{DISCUSSION}

It is currently the fashion to assign antibiotics to one of three groups with respect to their primary biochemical mechanism of action: $(a)$ suppression of cell wall synthesis, $(b)$ suppression of protein synthesis, $(c)$ disruption of lipoprotein membranes. In group $(a)$ have been placed penicillin, cycloserine and bacitracin (Park, 1960); in group (b) chloramphenicol, the tetracyclines, erythromycin, puromycin, streptomycin (Park, 1960; Brock \& Brock, 1959; Creaser, 1955; Yarmolinsky \& de la Haba, 1959); in group (c) gramicidin S, polymyxin, subtilin, tyrocidin (Newton, 1958). At concentrations in excess of those needed to inhibit growth, chlortetracycline (but not oxytetracycline) possesses activity $(a)$ as well as (b) (Park, 1960), and penicillin possesses activity $(b)$ as well as $(a)$ (Creaser, 1955). No antibiotic, however, has been stated thus far to be active at minimal growth inhibitory concentrations in more than one of the three categories. Nevertheless, the results described in the present study together with those obtained by Gale \& Folkes (1955) by Creaser (1955), and by Park (1958, 1960) indicate clearly that bacitracin, unlike 
penicillin, cycloserine and chloramphenicol, possesses at minimal bacteriostatic concentrations both activities $(a)$ and $(b)$, i.e. suppression of cell wall synthesis and protein synthesis.

Bacitracin is also unique in that, of the four antibiotics tested, it alone can stimulate the reduction of TTC by Staphylococcus aureus. This observation has been confirmed by Dr S. C. Lippincott (VA Center, Bay Pines, Florida, U.S.A.; personal communication). The stimulation of reduction of TTC may be a manifestation of enhancement by the bacitracin of cellular permeability. However, in subsequent studies (to be published) we have observed that bacitracin is considerably less active than such cationic surfactants as cetyltrimethylammonium bromide with respect to ability to lower the surface tension of water and to induce the release of nitrogenous constituents from non-multiplying cocci of $S$. aureus.

In the present study, bacitracin-induced protoplasts of Staphylococcus aureus could not be obtained. Similar tests by K. Crawford were stated to have yielded protoplasts (Abraham, 1957) but the details of these experiments have not yet been published. Likewise, it is quite difficult to obtain bacitracin-resistant variants in either in vitro (Stone, 1949; Gezon, Fasan \& Collins, 1950) or in vivo (Lowbury, 1960) systems. The instability of protoplasts and the lack of emergence of drugresistant variants may be a consequence of the fact that, at minimal growth inhibitory concentrations, multiple rather than single biochemical lesions are produced by bacitracin.

Molecules of bacitracin A probably exist as resonating and tautomeric structures (Craig, Konigsberg \& Hill, 1958) and when heated, stored, or placed in solution, may undergo a stepwise series of changes to progressively less active forms. The thermal and storage stability of the most biologically active form of bacitracin is preserved by allowing the molecule to form a complex with $\mathrm{Zn}^{2+}$ (Gross, 1954); possibly the dependence on $\mathrm{Zn}^{2+}$ of the bacteriostatic and bacteriolytic properties of bacitracin indicate that these two activities require a single stabilized molecular configuration. The precise binding site for $\mathrm{Zn}^{2+}$ on the bacitracin molecule is unknown; however, Garbutt, Morehouse \& Hanson (1961) postulated that $\mathrm{Zn}^{2+}$ (as well as $\mathrm{Cu}^{2+}, \mathrm{Ni}^{2+}$, and $\mathrm{Co}^{2+}$ ) is bound by the imidazole group of the histidine moiety of bacitracin $A$. It is possible that the formation of a metal bridge between the $\alpha$-amino group of isoleucine and the imidazole moiety would stabilize the molecule and prevent transformation to an inactive form. Indeed, since there is a 100-fold difference in bacteriostatic action depending on whether the medium is enriched with $\mathrm{Zn}^{2+}$ or with a zinc-binding agent (Weinberg, 1959, and this paper), it is probable that in the complete absence of available $\mathrm{Zn}^{2+}$ bacitracin would possess no bacteriostatic property whatsoever.

Alternately, $\mathrm{Zn}^{2+}$ may be required for the attachment of bacitracin to sensitive enzymes involved in the bacteriostatic and bacteriolytic actions but not those that are operative in induced enzyme synthesis or in the stimulation of TTC reduction. Additional evidence that the bacteriostatic property is distinct from the three other activities of bacitracin was obtained by exposing solutions of the drug to $121^{\circ}$ for different periods of time and observing the differential rates at which each property was inactivated. It must be concluded that the actual primary mechanism of the antibacterial action of bacitracin remains unknown. The results of previous and present investigations have shown only that (1) at minimal growth inhibitory 
concentrations, bacitracin can prevent cell wall synthesis, and also enzyme synthesis and perhaps enhance permeability, and (2) at subinhibitory concentrations, the compound can stimulate growth of various microbes (Novosel, 1961), germ-free plants (Nickell \& Finlay, 1954), birds and mammals (Goldberg, 1959). Clearly, a substance that possesses such an array of fascinating activities merits further investigation.

One of us (J.L.S.) wishes to acknowledge the financial support provided by a pre-doctoral United States Public Health Service fellowship. This work was done with the aid of grants from Commercial Solvents Corporation and from the National Institute of Allergy and Infectious Diseases, U.S.P.H.S. (Grants E-2252 C1 and C2). It was presented in part at the annual meeting of the American Society for Microbiology held in Chicago, 23-27 April, 1961.

\section{REFERENCES}

Abraham, E. P. (1957). Biochemistry of Some Peptide and Steroid Antibiotics. New York: John Wiley and Sons, Inc.

Abraham, E. P. \& Newton, G. G. F. (1958). Structure and function of some sulphurcontaining peptides. In CIBA Foundation Symposium on amino acids and peptides with antimetabolic activity, p. 205. Ed. G. W. S. Wolstenholme and C. M. O'Connor. London: J. and A. Churchill, Ltd.

Brock, T. D. \& Brock, M. L. (1959). Similarity in mode of action of chloramphenicol and erythromycin. Biochim. biophys. Acta, 33, 273.

Craig, L. C., Konigsberg, W. \& Hill, R. J. (1958). Bacitracin. In CIBA Foundation Symposium on amino acids and peptides with anti-metabolic activity, p. 226. Ed. G. W. S. Wolstenholme and C. M. O'Connor. London: J. and A. Churchill, Ltd.

Crawford, K. \& Abraham, E. P. (1957). The synergistic action of cephalosporin C and benzylpenicillin against a penicillinase-producing strain of Staphylococcus aureus. J.gen . Microbiol. 16, 604.

Creaser, E. H. (1955). The induced (adaptive) biosynthesis of $\beta$-galactosidase in Staphylococcus aureus. J. gen. Microbiol. 12, 288.

Gale, E. F. \& Folkes, J. P. (1955). The assimilation of amino-acids by bacteria. 21. The effect of nucleic acids on the development of certain enzymatic activities in disrupted staphylococcal cells. Biochem. J. 59, 675 .

Garbutt, J. T., Morehouse, A. L. \& Hanson, A. M. (1961). Feed additives, metal binding properties of bacitracin. J. Agric. Fd Chem. 9, 285.

Gezon, H. M., Fasan, D. M. \& Collins, G. R. (1950). Antibiotic studies on beta hemolytic streptococci: VII. Acquired in vitro resistance to bacitracin. Proc. Soc. Exp. Biol., N.Y. 74, 505.

Goldberg, H. S. (ed.) (1959). Antibiotics. Their Chemistry and Non-medical Uses. Princeton, N.J., U.S.A.: D. Van Nostrand Co.

Gross, H. M. (1954). Zinc bacitracin in pharmaceutical preparations. Drug. Cosmet. Ind. $75,612$.

Hinton, N. A. \& ORR, J. H. (1960). The effect of antibiotics on the toxin production of Staphylococcus aureus. Antibiot. \& Chemother. 10, 758.

Lederberg, J. (1950). The beta-D-galactosidase of Escherichia coli, strain K-12. J. Bact. 60, 381.

LowBURy, E. J. L. (1960). Clinical problems of drug-resistant pathogens. Brit. med. Bull. $16,73$.

MANDELSTAM, J. \& RoBers, H. J. (1959). The incorporation of amino acids into the cellwall mucopeptide of staphylococci and the effect of antibiotics on the process. Biochem.J. 72,654 . 
Newton, B. A. (1958). Surface-active bactericides. In The Strategy of Chemotherapy. Symp. Soc. gen. Microbiol. 8, 62.

Nickell, L. G. \& Finlay, A. C. (1954). Growth modifiers, antibiotics and their effects on plant growth. J. Agric. Fd Chem. 2, 178.

Novosel, D. L. (1961). Studies on the nutritional action of bacitracin. A. M. Thesis, Indiana University, Bloomington, Indiana, U.S.A.

Park, J. T. (1958). Inhibition of cell-wall synthesis in Staphylococcus aureus by chemicals which cause accumulation of wall precursors. Biochem. J. 70, 2 P.

PARK, J. T. (1960). Inhibition of synthesis of bacterial muco-peptides or protein by certain antibiotics and its possible significance for microbiology and medicine. In Antimicrobial Agents Annual 1960, p. 338. New York: Plenum Press, Inc.

Robinson, H. W. \& Hogden, C. C. (1940). The biuret reaction in the determination of serum proteins. J. biol. Chem. 135, 707.

Stone, J. L. (1949). Induced resistance to bacitracin in cultures of Staphylococcus aureus. J. infect. Dis. 85, 91.

WeInBERG, E. D. (1957). The mutual effects of antimicrobial compounds and metallic cations. Bact. Rev. 21, 46.

WEINBERG, E. D. (1959). Enhancement of bacitracin by metallic ions of group IIB. In Antibiotics Annual 1958-1959, p. 924. Ed. H. Welch and F. Marti-Ibanez. New York: Medical Encyclopedia, Inc.

YaRmolinsky, M. B. \& DE LA Hara, G. L. (1959). Inhibition by puromycin of amino acid incorporation into protein. Proc. nat. Acad. Sci., Wash. 45, 1721. 